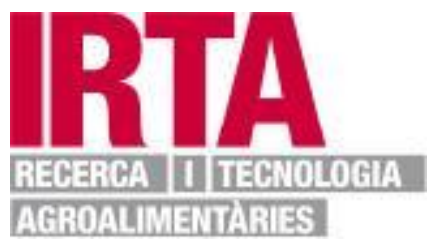

This document is a postprint version of an article published in Meat Science, copyright $\odot$ Elsevier B.V. after peer review.

To access the final edited and published work see:

http://dx.doi.org/10.1016/j.meatsci.2012.10.014 


\section{Surface-Enhanced Laser Desorption/Ionisation Time-of-Flight Mass Spectrometry: a Tool to Predict Pork Quality}

Marcos, B. ${ }^{1}$, Gou, P. ${ }^{1}$, Guàrdia, M.D. ${ }^{1 *}$, Hortós, M. ${ }^{1}$, Colleo, M. ${ }^{1}$, Mach, N. ${ }^{2}$, te Pas, M.F.W. ${ }^{2}$, Keuning, E. ${ }^{2}$, Kruijt, L. ${ }^{2}$, Tibau, J. ${ }^{1}$, Gispert, M. ${ }^{1}$, Arnau, J. ${ }^{1}$

${ }^{1}$ IRTA-Food Technology, 17121 Monells, Girona, Spain

2 Animal Breeding and Genomics Centre, Wageningen UR Livestock Research, PO Box 65, 8200 AB Lelystad, the Netherlands

Keywords: meat quality, pure breeds, SELDI-TOF-MS, protein markers

*corresponding author: dolors.guardia@irta.cat 


\begin{abstract}
Expression of water soluble proteins of fresh pork Longissimus thoracis from 4 pure breed pigs (Duroc, Large White, Landrace, and Piétrain) was studied to identify candidate protein markers for meat quality. Surface-enhanced laser desorption/ ionisation time-of-flight mass spectrometry (SELDI-TOF-MS) was used to obtain the soluble protein profiles of Longissimus thoracis muscles. The pure breeds showed differences among the studied meat quality traits $\left(\mathrm{pH}_{\mathrm{u}}\right.$, drip loss, androstenone, marbling, intramuscular fat, texture, and moisture), but no significant differences were detected in sensory analysis. Associations between protein peaks obtained with SELDITOF-MS and meat quality traits, mainly water holding capacity, texture and skatole were observed. Of these peaks, a total of 10 peaks from CM10 array and 6 peaks from Q10 array were candidate soluble protein markers for pork loin quality. The developed models explained a limited proportion of the variability, however they point out interesting relationships between protein expression and meat quality.
\end{abstract}




\section{Introduction}

From a consumer point of view, meat quality is defined as the eating quality or palatability of meat. This concept covers quality attributes such as texture, mainly tenderness, meat colour, water holding capacity (WHC), and flavour. Variation in meat quality is a detrimental factor for meat acceptability and causes appreciable economic losses for meat producers. Thus, it is essential for the meat industry to have methods to facilitate the assurance, control, and optimization of product quality. Recent high throughput proteomic approaches can assist research towards this goal.

Surface-enhanced laser desorption/ ionisation time-of-flight mass spectrometry (SELDITOF-MS) combines chromatographic techniques and mass spectral measurement. The SELDI chip contains chromatographic coatings of selected types (i.e. hydrophobic, ionexchange, metal-binding, etc.), on which sample components with complementary physicochemical properties are bound (O’Gorman et al., 2006). Unbound compounds are washed off, thus contaminants are removed and sample complexity is markedly reduced. After application of a proper energy-absorbing matrix, proteins bound to the stationary phase are analysed by MS profiling (Bodzon-Kulakowska et al., 2007). A proteomic approach using SELDI-TOF-MS can identify the expression of complex protein patterns or single protein markers in muscle tissue based on the mass-to-chargeratio of the proteins and on their binding affinity to the protein arrays. Because it is not necessary to know the identity of the proteins for the purpose of differential classification, this technology provides an alternative platform for the differential display of multiple potential markers (Mach, Keuning, Kruijt, Hortos, Arnau \& te Pas, 2010).

In a previous work, Mach et al. (2010) detected potential protein markers from Longissimus thoracis muscle that could be used to classify raw hams by breed type (Duroc, Large White, Landrace, and Piétrain). The animals from Mach et al. (2010) were used in the present study to assess the differences between breeds on the carcass 
and quality parameters of pork. Besides, this work also aimed to investigate of the relationships between protein fingerprinting in Longissimus thoracis muscle and the final quality of cooked pork loin.

\section{Materials and methods}

\section{Animals}

One hundred and twenty entire male pigs from four pure breeds were studied. Duroc (DU, $n=21$ ), Landrace (LR, $n=43)$, Large White (LW, $n=43$ ) and Piétrain (PI, $n=$ 13) pigs were fattened under identical conditions in the Pig Testing Station (IRTACAP) in Monells (Girona, Spain). The four pig genetic types (DU, LR, LW, PI) were reared under the same conditions of housing, environment and feeding, and the ante mortem handling was performed under low stress conditions. Therefore, the experiment allowed the comparison between lines with minimum interference from external influences. Average daily gain and average daily feed intake were recorded. Feed conversion ratio was calculated dividing the amount of feed consumed by the corresponding body weight gain.

The animals were weighed one day before slaughter. The average age (days) was $174 \pm$ 6 for DU, $176 \pm 6$ for LR, $172 \pm 6$ for LW, and $177 \pm 9$ for PI. The pigs were fasted onfarm during $9 \mathrm{~h}$ and transported for $1.5 \mathrm{~h}$ to a commercial slaughterhouse in Vic (Spain). Animals from different pens were not mixed. The animals were slaughtered in two different days. Each slaughtering batch contained a group of pigs representing all the studied breeds. Slaughtering was performed using $\mathrm{CO}_{2}$ stunning at $90 \%$ of concentration for $2 \mathrm{~min}$.

\section{Carcass measurements}

Back fat and loin muscle thickness were measured for each carcass within $1 \mathrm{~h}$ post mortem at $60 \mathrm{~mm}$ from the mid-line between the $3^{\text {rd }}$ and $4^{\text {th }}$ last rib ( $\mathrm{f} 34 \mathrm{fom}$ and m34fom, respectively) using the Fat-O-Meat'er probe (Carometec, AS, Herlev, DK). 
These parameters were used to estimate the lean meat content of the carcass as suggested in the Commission Decision 2009/11/CE (European Commission, 2009):

$$
\text { Estimated lean }(\%)=66.91-0.895 \times \text { f34fom }+0.144 \times \mathrm{m} 34 \text { fom }
$$

Where f34fom and m34fom are the fat and the muscle depth measured with Fat-OMeat'er, respectively.

Carcasses were chilled at $3 \pm 1^{\circ} \mathrm{C}$. At $24 \mathrm{~h}$ post mortem carcasses were weighed, and loin length (from the first lumbar vertebrae to the atlas bone) and carcass length (from the anterior edge of the pubic symphysis to the recess of the first rib) were measured.

\section{Meat quality measurements}

Meat quality was assessed on the left side of each carcass. Fifteen mm-thick samples of Longissimus thoracis were taken between the $2^{\text {nd }}$ and $3^{\text {rd }}$ last ribs for meat quality measurements and stored at $4 \pm 2{ }^{\circ} \mathrm{C}$ until analysis.

Drip loss was determined at $24 \mathrm{~h}$ post mortem, following the reference method supported by OECD (Honikel, 1998) to assess water holding capacity. Muscle pH was measured at $24 \mathrm{~h}$ post mortem $(\mathrm{pHu})$ with a Xerolyt ${ }^{\circledR} \mathrm{pH}$ electrode on a portable $\mathrm{pH}$ meter (Crison pH 25, Crison Instruments, SA, Alella, Spain).

Colour measurements were carried out with a Minolta CM 2002 (Minolta Co., Ltd., Osaka, Japan) spectrophotometer (illuminant D65, $10^{\circ}$ standard observer and the specular component included) in the CIELAB space: lightness $\left(\mathrm{L}^{*}\right)$, redness $\left(\mathrm{a}^{*}\right)$ and yellowness $\left(b^{*}\right)$. Colour measurements were carried out on the slice surface and averaged over five zones. Moisture, fat, protein, and collagen contents were measured by near infrared transmittance spectroscopy FoodScan ${ }^{\circledR}$ (FOSS Electric A/S, Denmark).

Samples for texture and sensory analysis were individually wrapped in aluminium foil and cooked in a pre-heated electric oven at $110^{\circ} \mathrm{C}$ until a core temperature of $70{ }^{\circ} \mathrm{C}$ was reached. After cooking, samples for sensory analysis were tested immediately, while 
samples for texture analysis were cooled down at room temperature before analysis. The weight of each sample was recorded before and after cooking. Cooking loss was expressed as the percentage of the weight difference after cooking.

Texture was assessed using the Texture Profile Analysis (TPA) and the Warner-Bratzler shear force test (WBSF) using a Texture Analyser TA.TX2 (Stable Micro systems Ltd.) with a $25 \mathrm{~kg}$ load cell. Five specimens of $20 \mathrm{~mm} \times 20 \mathrm{~mm} \times 15 \mathrm{~mm}$ were obtained for each sample. The samples were compressed to $75 \%$ of their original height perpendicular to the muscle fibre direction and at a crosshead speed of $1 \mathrm{~mm} / \mathrm{s}$. Analyses of the force-time curve lead to the extraction of several textural parameters: hardness (kg), cohesiveness (dimensionless), springiness (dimensionless), and chewiness (kg) (Bourne, 1978). WBSF test was performed using a WB shear blade with a triangular slot cutting edge and four parameters were measured: initial yield force, maximum shear force, shear firmness, and total work (Brady \& Hunecke, 1985; Møller, 1980). Five specimens of $20 \mathrm{~mm} \times 10 \mathrm{~mm} \times 10 \mathrm{~mm}$ were obtained for each sample. Each sample was sheared perpendicular to muscle fibres.

Determination of androstenone was performed as described by Rius, García-Regueiro \& Hortós (2005) and Ampuero Kragten et al. (2011). Subcutaneous neck fat samples (1.00 $\pm 0.01 \mathrm{~g})$ were homogenised and extracted in $50 \mathrm{~mL}$ hexane: dichloromethane (50:50) containing $5 \alpha$-androstan-3-one $(2 \mu \mathrm{g} / \mathrm{g})$ as internal standard. Extracts were purified in a solid phase extraction (SPE) Diol column and the collected fraction was further purified in a C18 SPE column. The residues were injected in a gas chromatographer coupled to a mass spectrometry detector (Varian 3800 - Saturn 2200 Varian, Inc. Corporate Headquarters, Palo Alto, CA, USA). A capillary column BPX5 (SGE, Australia), 30m × $0.25 \mathrm{~mm}(0.25 \mu \mathrm{m}$ film thickness $)$ was used. Mass spectrometry data was acquired in SIM mode with m/z: 257 and 272 (target) and 202, 274. Androstenone concentration was quantified after spiking a control adipose tissue sample that had no detectable amount of androstenone. All samples were evaluated in duplicate. 
Skatole (3-methylindole) content was determined using the method described by García-Regueiro and Rius (1998). One gram samples were weighed (precision $\pm 0.01 \mathrm{~g}$ ), and $500 \mathrm{ng}$ of 7-ethylindole were added as an internal standard. Skatole was extracted in a $10 \mathrm{~mL}$ solution of hexane:2-propanol (92:8). The extracts were injected into an HPLC system (Agilent, Santa Clara CA, USA) for determination and the separation was performed on a Hypersil column aminopropylsilica-2 $(5 \mu \mathrm{m}, 250 \times 4.6 \mathrm{~mm})$ under a flow of $1.5 \mathrm{ml} / \mathrm{min}$ using a solution of hexane: 2-propanol (92:8) as a mobile phase. Detection was performed by fluorescence (280 $\mathrm{nm}$ excitation and $360 \mathrm{~nm}$ emission wavelengths). Skatole and indole concentrations were quantified after spiking a control adipose tissue sample. All samples were evaluated in duplicate.

\section{Quantitative Descriptive Analysis (QDA)}

Sensory characterization of the samples was performed through a Qualitative Descriptive Analysis (QDA) using 6 selected trained assessors (ASTM, 1981; ISO, 1993, 1994). The generation and selection of the descriptors were carried out by open discussion during three sessions of $1 \mathrm{~h}$ each. The descriptors retained for raw and cooked meat are described in Table 1. A non-structured scoring scale (Amerine, Pangborn \& Roessler, 1965) was used, where 0 and 10 meant absence and high intensity of the descriptor, respectively.

Sensory evaluation was undertaken in 25 sessions. Five samples per session were analysed in 20 sessions and 4 samples in the other 5 sessions. All sessions were performed in a six-booth sensory panel room at a $20 \pm 2^{\circ} \mathrm{C}$ equipped with red fluorescent lighting to mask the red colour of the cooked meat. Appearance attributes of raw meat were evaluated under white lighting $(700 \pm 150 \mathrm{~lx})$. During each session at least three samples from different breeds and a maximum of two samples per breed were analysed. Samples were coded with three random numbers and were presented to the assessors balancing the first-order and the carry-over effects as much as possible, 
according to MacFie, Bratchell, Greenhoff, and Vallis (1989). The average score of the seven assessors for each sample was calculated using the assessor as a block effect in the statistical analysis.

\section{Preparation of Protein Extracts for SELDI-TOF Analyses}

After $24 \mathrm{~h}$ of carcass chilling, a sample of Longissimus thoracis muscle was removed from each animal, frozen in liquid nitrogen, and stored at $-80^{\circ} \mathrm{C}$ until used. Muscle samples were weighed (30 to $50 \mathrm{mg}$ ), placed in $1.5 \mathrm{~mL}$ of lysis buffer [10 $\mathrm{mM}$ Tris-HCl, $\mathrm{pH} 7.25,10 \mathrm{mM} \mathrm{KCl}, 2 \%$ (vol/vol) Triton X-100, $1 \mathrm{mM} \mathrm{PMSF}]$, and homogenized (Ultraturrax T25, IKA Labortechnik, Staufen, Germany) in ice. Sample homogenates were centrifuged for $20 \mathrm{~min}$ at $12,000 \times \mathrm{g}$ and $4^{\circ} \mathrm{C}$. Total protein content of the supernatant was analysed with a commercial BSA protein assay kit (Bio-Rad, Veenendaal, the Netherlands).

\section{SELDI-TOF-MS Analyses}

The strong anion exchanger (Q10), weak cation exchanger (CM10), and immobilized metal affinity capture (IMAC30) (Bio-Rad Laboratories Inc., Hercules, CA) protein arrays were selected because they produce good quality proteome patterns with an optimal number of peaks (te Pas, Jansen, Broekman, Reimert \& Heuven, 2009). Array preparation and sample loading were performed as described by Mach et al. (2010).

The different protein arrays were placed in the SELDI protein arrays Biology System Reader 4,000 (Bio-Rad Laboratories Inc.). The laser intensity was 3,000 nJ. The SELDI protein array spectra were further normalised and analysed as explained by Mach et al. (2010). All samples were analysed in duplicate. 
Data were analysed using the GLM procedure of SAS 9.2 (SAS Institute Inc., Cary, NC, USA). The model for carcass measurements, physicochemical data included breed as fixed effect and slaughtering batch as a block effect. The model for sensory analysis also included session as a block effect. Animal weight was included as a covariable in the model for carcass measurements. Differences among breeds were assessed using the Tukey test. The level of significance was set at $\mathrm{p}<0.05$.

Pearson correlation analysis was used to investigate the relationship among meat quality variables and protein peaks. Correlation coefficients were calculated with the CORR procedure of SAS 9.2 for each protein peak within the protein chip arrays type. A multiple testing correction consisting of a modification of the effective number (Cheverud, 2001) was performed as suggested by Li \& Ji (2005).

Regression models of the quality properties of cooked loins on peak intensities and meat quality parameters (carcass measurements and quality measurements of raw meat) were fitted for each protein array (CM10, Q10, \& IMAC30) with the REG procedure of SAS 9.2, using the stepwise regression method. Significant levels were set at $p=0.15$ to enter variables in the model and at $\mathrm{p}=0.05$ to be kept in the model.

\section{Results and discussion}

\section{Influence of breed on growth performance, carcass characteristics and meat quality}

Growth, carcass, and meat quality measurements presenting significant differences between breeds are shown in Table 2. Pigs from Piétrain (PI) breed showed lower average daily feed intake and feed conversion ratio than the other breeds. Therefore, PI pigs were smaller at the moment of slaughter and yielded smaller carcasses than other breeds, except for Landrace.

However, the killing-out percentage in PI was significantly higher compared to LW and LR, but not DU. Fat depth measurements (f34fom) were lower for PI carcasses compared to other breeds, as a result PI showed the highest estimated lean percentage. 
PI pigs are heavily muscled animals with carcasses showing less fat depth and higher muscular area and lean content than other breeds, a factor of interest for the meat industry (Guerrero, Gou, Alonso \& Arnau, 1996; Plastow et al., 2005).

PI presented the highest drip loss, while DU showed the lowest values. In general, DUsired pigs show higher water holding capacity (WHC) than PI-sired lines (Latorre, Lazaro, Gracia, Nieto \& Mateos, 2003; Oliver et al., 1994). The higher drip loss in PI meat is a consequence of the fast $\mathrm{pH}$ drop observed in this breed immediately after slaughter, resulting in greater protein denaturation and elevated water loss (Bowker, Grant, Forrest \& Gerrard, 2000; Offer, 1991). These high levels of drip loss are usually related to meat quality problems, however, no significant differences on the technological and sensory characteristics of PI meat were observed in the present study compared with other breeds.

As expected, DU loins showed the highest intramuscular fat (IMF) content. Similarly, Plastow et al. (2005) reported the highest values of IMF in Duroc lines compared with LR, LW and PI. Visual inspection of loins confirmed higher marbling in DU although not significantly different from LR, and the lowest scores were for PI loins. Duroc also showed significantly higher values of androstenone than the other studied breeds (Table 2). Genetic variation has been reported for fat androstenone concentration, both between breeds and within a breed (Allen, 2003; Varona et al., 2005; Xue et al., 1996). DU pigs tend to have higher levels of androstenone than other breeds (Fredriksen et al., 2006; Hortós, Rius, De Vries, Lacoste, Gispert \& Diestre, 2000).

Instrumental Texture Analysis (TPA), showed higher values of hardness and chewiness in LR loins compared to DU and PI. DU loins presented the lowest values for cohesiveness. Finally, no significant differences among breeds were detected by the trained assessors for any of the evaluated sensory traits $(\mathrm{p}>0.05)$. 
Tables 3-5 show correlations between meat quality parameters and protein peak profiles. Proteins correlated with quality traits were in a range of 3,000 to $17,000 \mathrm{~m} / \mathrm{z}$ ratio. Correlation analysis reflected that proteome profiles obtained with CM10 protein array presented more protein peaks associated with quality properties of cooked loins than the other arrays tested (Table 3). The same fact was previously observed for drycured hams (Marcos et al., in press). These results suggest that the subset of proteins bound to CM10 protein arrays at the studied conditions, would have stronger influence on the quality parameters of the studied meat products that the proteins bound on the other protein arrays. The CM10 protein arrays are cation exchange arrays, suggesting that positively charged proteins are important for meat quality traits. Among the protein peaks detected with CM10 array, 15 peaks were correlated with drip loss and cooking loss, androstenone, instrumental and sensory texture, visual colour, and skatole flavour (Table 3). Correlations of peaks 12, 223 and 12,434 m/z with drip loss ( $\mathrm{r}=0.360$ and 0.408 , respectively), cooking loss ( $\mathrm{r}=0.368$ and 0.339 , respectively) and juiciness ( $\mathrm{r}=-$ 0.290 and -0.313 , respectively) were observed. These results would suggest the role of these two protein peaks on water holding capacity of meat. The relationship of protein peaks with instrumental and sensory texture measurements was observed. Specifically peaks 4,338 and $8,485 \mathrm{~m} / \mathrm{z}$ were positively correlated with initial yield force and sensory hardness. These peaks were also positively correlated with cooking loss and negatively correlated with sensory juiciness, indicating that increased peak intensity would be related to increased cooking loss, while higher toughness. On the contrary, peak $8,464 \mathrm{~m} / \mathrm{z}$ was negatively correlated with initial yield force and cooking loss, and positively correlated with juiciness. Te Pas et al. (2009) reported that meat proteolysis profiles were associated with drip loss and shear force measurements. Therefore, the detected peaks related to cooking loss and texture could be associated with protein degradation products. 
For Q10 array, we observed ten protein peaks correlated with colour, drip and cooking loss, and initial yield force and sensory hardness (Table 4). Peak 12,119 m/z showed a negative correlation with drip loss and cooking loss ( $r=-0.340$ and -0.355 , respectively). Finally, four protein peaks obtained with IMAC30 array were correlated with a* values, initial yield force, cooking loss, marbling and sweetness (Table 5). To further confirm the implication of these protein peaks in the final quality of cooked loins, regression models for sensory and technological quality properties were obtained including peak intensities and other carcass and meat quality parameters as independent variables (Table 6). For CM10 array, we obtained regression models for drip and cooking loss, instrumental and sensory texture (cohesiveness, total work and sensory hardness), and chemical and sensory skatole data. It should be highlighted that peak $12,434 \mathrm{~m} / \mathrm{z}$ was retained in the models for both drip and cooking loss. Similarly, the models for both total work measured with WBSF test and sensory hardness presented peak 4,338 in common. Another interesting result was the inclusion of the same peak, 9,398 m/z, in the models for skatole content and skatole flavour.

Models for drip and cooking loss, and total work were fitted with data obtained with Q10 protein arrays. Peak $12,119 \mathrm{~m} / \mathrm{z}$ was retained in the model for both drip and cooking loss. These results confirm the relationship between the expression of protein peaks in the range of $12,000 \mathrm{~m} / \mathrm{z}$ and water holding capacity of pork loin. Other authors have reported the relationship between soluble protein profiles and water holding capacity of meat (Di Luca, Mullen, Elia, Davey \& Hamill, 2011; Marcos, Kerry \& Mullen, 2010; Sayd et al., 2006). Finally, no significant models were obtained with IMAC30 protein arrays. Considering that IMAC30 protein arrays are used for phosphorylated protein capture, this result would suggest that phosphorylated proteins were less involved in the determination of quality variation. Apart from the reported protein peaks, other meat and carcass quality parameters retained in the reported models were mainly estimated carcass lean, $\mathrm{pH}_{\mathrm{u}}$, loin yield, IMF and backfat thickness. 
Although these models explain a small proportion of the variability, they point out interesting relationships between the expressed proteins and meat quality traits. The development of meat quality traits is a complex biological process influenced by many factors such as breeds, treatments, or other unknown factors. The power of candidate markers to explain variation remains unclear, but it is certain that they contribute to building a better picture of this complex process (Hollung and Veiseth-Kent, 2012).

Knowing the biological mechanism regulating an economically interesting trait opens up a possibility of monitoring and modulating the trait through breeding programmes (te Pas and Hoekman, 2011). Moreover, the detection of these markers at the moment of slaughter would help to predict the final quality of meat. The development of fast detection methods would provide a carcass classification system as a function of the predicted meat quality. However, validation and identification of these protein markers in other datasets considering other environmental and processing factors that contribute to the variability of meat quality would be needed.

\section{Conclusions}

Although some quality differences were found among the studied pure breeds (DU, LR, LW, PI), no significant differences were detected in the sensory analysis.

Candidate soluble protein markers for quality of loins were identified. The developed models explained a limited proportion of the variability, however they point out interesting relationships between between protein expression and meat quality.The detection of these biomarkers in the raw material would help to predict the final quality of meat and would provide us with a tool for raw material quality control. However, further validation of the involvement of these proteins in the quality of cooked pork loins is needed before considering them as protein markers. 
The authors gratefully acknowledge financial participation from the European Community under the $6^{\text {th }}$ Framework programme for Research, Technological Development and Demonstration Activities, for the Integrated Project QPorkchains FOOD-CT-2007-036245. The content of the paper reflects only the view of the authors; the Community is not liable for any use that may be made of the information contained in this paper. Furthermore, additional finances were from the Kennisbasis (Knowledge Base) grant no KB05-003-02 of the Dutch Ministry of Agriculture, Nature and Food security. The support of the Commission for Universities and Research of the Department of Innovation, Universities and Enterprise of the Autonomous Government of Catalonia is acknowledged.

\section{Bibliography}

Allen, P. (2003). Differences between four breeds in the incidence of boar taint and secondary sexual characteristics. In Proceedings EAAP Working Group "Production and Utilisation of Meat from Entire Male Pigs" 13-14 November 2003, Dublin, Ireland.

Amerine, M., Pangborn, R. \& Roessler, E. (1965). Principles of sensory evaluation of food. In (pp. New York: Academic Press.

Ampuero Kragten, S., Verkuylen, B., Dahlmans, H., Hortós, M., García-Regueiro, J. A., Dahl, E., Andresen, O., Feitsma, H., Mathur, P. K. \& Harlizius, B. (2011). Interlaboratory comparison of methods to measure androstenone in pork fat. Animal, 5 (10), 1634-1642.

ASTM. (1981). Guidelines for the selection and training of sensory panel members.ASTM Special Technical Publication 758,

Bodzon-Kulakowska, A., Bierczynska-Krzysik, A., Dylag, T., Drabik, A., Suder, P., Noga, M., Jarzebinska, J. \& Silberring, J. (2007). Methods for samples preparation in proteomic research. Journal of Chromatography B, 849 (1-2), 1-31.

Bourne, M. C. (1978). Texture profile analysis. Food Technology, 32 (7), 62-66, 72.

Bowker, B. C., Grant, A. L., Forrest, J. C. \& Gerrard, D. E. (2000). Muscle metabolism and PSE pork. Journal of Animal Science, 79 1-8.

Brady, P. L. \& Hunecke, M. E. (1985). Correlation of sensory and instrumental evaluations of roast beef texture. Journal of Food Science, 50 300-303.

Cheverud, J. M. (2001). A simple correction for multiple comparisons in interval mapping genome scans. Heredity, 87 52-58.

Di Luca, A., Mullen, A. M., Elia, G., Davey, G. \& Hamill, R. M. (2011). Centrifugal drip is an accessible source for protein indicators of pork ageing and water-holding capacity. Meat Science, 88 (2), 261-270. 
European Commission. (2009). Commission Decision of 19 December 2008 authorising methods for grading pig carcases in Spain (2009/11/CE). Official Journal of the European Communities, L 6/79-82, 10.1.2009.

Fredriksen, B., Lium, B. r. M., Marka, C. H., Heier, B. T., Dahl, E., Choinski, J. U. \& Nafstad, O. (2006). Entire male pigs in a farrow-to-finish system. Effects on androstenone and skatole. Livestock Science, 102 (1-2), 146-154.

García-Regueiro, J. A. \& Rius, M. A. (1998). Rapid determination of skatole and indole in pig back fat by normal-phase liquid chromatography. Journal of Chromatography A, 809 (246),

Gispert, M. \& Diestre, A. (1994). Classement des carcasses de porc en Espagne : un pas vers l'harmonization communautaire. Techni-Porc, 17 (2), 29-32.

Guerrero, L., Gou, P., Alonso, P. \& Arnau, J. (1996). Study of the Physicochemical and Sensorial Characteristics of Dry-Cured Hams in Three Pig Genetic Types. Journal of the Science of Food and Agriculture, 70 526-530.

Hollung, K. \& Veiseth-Kent, E. (2012). Molecular understanding of tenderness: a proteomics approach. In Proceedings 58th International Congress of Meat Science, paper 441, Montreal, Canada.

Honikel, K. O. (1998). Reference methods for the assessment of physical characteristics of meat. Meat Science, 49 (4), 447-457.

Hortós, M., Rius, M. A., De Vries, A., Lacoste, A., Gispert, M. \& Diestre, A. (2000). Variation of boar taint compounds in backfat from divergent genetic lines. In Proceedings 46th International Congress of Meat Science, pp.98-99, Buenos Aires, Argentina.

ISO. (1993). ISO 8586-1. Sensory analysis. General guidance for the selection, training and monitoring of assessors. Part 1: Selected assessors. International Organisation for Standarisation.

ISO. (1994). ISO 8586-2. Sensory analysis. General guidance for the selection, training and monitoring of assessors. Part 2: Experts. International Organisation for Standarisation.

Latorre, M. A., Lazaro, R., Gracia, M. I., Nieto, M. \& Mateos, G. G. (2003). Effect of sex and terminal sire genotype on performance, carcass characteristics, and meat quality of pigs slaughtered at $117 \mathrm{~kg}$ body weight. Meat Science, 65 (4), 1369-1377.

Laville, E., Sayd, T., Terlouw, C., Chambon, C., Damon, M., Larzul, C., Leroy, P., Glenisson, J. \& Cherel, P. (2007). Comparison of Sarcoplasmic Proteomes between Two Groups of Pig Muscles Selected for Shear Force of Cooked Meat. J. Agric. Food Chem., 55 (14), 5834-5841.

Li, J. \& Ji, L. (2005). Adjusting multiple testing in multilocus analysis using the eigenvalues of a correlation matrix. Heredity, 95 221-227.

Macfie, H. J., Bratchell, N., Greenhoff, K. \& Vallis, L. (1989). Designs to balance the effect of order of presentation and first-order carry-over effects in hall tests. Journal of Sensory Studies, 4 (2), 129-148.

Mach, N., Keuning, E., Kruijt, L., Hortos, M., Arnau, J. \& te Pas, M. F. W. (2010). Comparative proteomic profiling of 2 muscles from 5 different pure pig breeds using surface-enhanced laser desorption/ionization time-of-flight proteomics technology. Journal of Animal Science, 88 (4), 1522-1534.

Marcos, B., Kerry, J. P. \& Mullen, A. M. (2010). High pressure induced changes on sarcoplasmic protein fraction and quality indicators. Meat Science, 85 (1), 115-120.

Marcos, B., Gou, P., Serra, X., Guàrdia, M. D., Zhen, Z., Hortós, M., Mach, N., te Pas, M. F. W., Keuning, E., Kruijt, L., Font i Furnols, M. \& Arnau, J. (in press). Analysis of raw hams using SELDI-TOF-MS to predict the final quality of dry-cured hams. Meat Science, http://dx.doi.org/10.1016/j.bbr.2011.03.031. 
Møller, A. J. (1980). Analysis of Warner-Bratzler shear pattern with regard to myofibrillar and connective tissue components of tenderness. Meat Science, 5 247260.

O’Gorman, D., Howard, J. C., Varallo, V., Cadieux, P., Bowley, E., MacLean, K., Pak, B. \& Gan, B. S. (2006). Identification of protein biomarkers in Dupuytren's contracture using surface enhanced laser desorption ionisation time-of-flight mass spectrometry. Clinical Investigative Medicine, 29 136-145.

Offer, G. (1991). Modelling of the formation of pale, soft and exudative meat: Effects of chilling regime and rate and extent of glycolysis. Meat Science, 30 (2), 157-184.

Oliver, M. A., Gou, P., Gispert, M., Diestre, A., Arnau, J., Noguera, J. L. \& Blasco, A. (1994). Comparison of five types of pig crosses. II. fresh meat quality and sensory characteristics of dry cured ham. Livestock Production Science, 40 (2), 179-185.

Plastow, G. S., Carrión, D., Gil, M., Garcla-Regueiro, J. A., i Furnols, M. F., Gispert, M., Oliver, M. A., Velarde, A., Guàrdia, M. D., Hortós, M., Rius, M. A., Sárraga, C., Diaz, I., Valero, A., Sosnicki, A., Klont, R., Dornan, S., Wilkinson, J. M., Evans, G., Sargent, C., Davey, G., Connolly, D., Houeix, B., Maltin, C. M., Hayes, H. E., Anandavijayan, V., Foury, A., Geverink, N., Cairns, M., Tilley, R. E., Mormède, P. $\&$ Blott, S. C. (2005). Quality pork genes and meat production. Meat Science, 70 (3), 409-421.

Rius, M. A., García-Regueiro, J. A. \& Hortós, M. (2005). Influence of volatile compounds on the development of off-flavours in pig back fat samples classified with boar taint by a test panel. Meat Science, 71 595-602.

Sayd, T., Morzel, M., Chambon, C., Franck, M., Figwer, P., Larzul, C., LeRoy, P., Monin, G., Cherel, P. \& Laville, E. (2006). Proteome analysis of the sarcoplasmic fraction of pig Semimembranosus muscle: Implications on meat color development. Journal of Agricultural and Food Chemistry, 54 (7), 2732-2737.

Simpson, S. P., Weeb, A. J. \& Dick, S. (1987). Evaluation of Large White and Duroc boars as terminal sires under two different feeding regimes. Animal Production, 45 111-116.

te Pas, M. F. W., Jansen, J., Broekman, K. C. J. A., Reimert, H. \& Heuven, H. C. M. (2009). Postmortem proteome degradation profiles of longissimus muscle in Yorkshire and Duroc pigs and their relationship with pork quality traits. Meat Science, 83 (4), 744-751.

te Pas, M. F. W., Hoekman, A. J. W. \& Smits, M. A. (2001). Biomarkers as management tools for industries in the pork production chain. Journal on Chain and Network Science 11(2): 155-166.

Varona, L., Vidal, O., Quintanilla, R., Gil, M., Sánchez, A., Folch, J. M., Horós, M., Rius, M. A., Amills, M. \& Noguera, J. L. (2005). Bayesian analysis of quantitative trait loci for boar taint in a Landrace outbred population. Journal of Animal Science, 83 (2), 301-307.

Xue, J., Dial, G. D., Holton, E. E., Vickers, Z., Squires, E. J., Lou, Y., Godout, D. \& Morel, N. (1996). Breed differences in boar taint: Relationship between tissue levels boar taint compounds and sensory analysis of taint. Journal of Animal Science, 74 2170-2177. 
Table 1. Definition of sensory parameters used in the Quantitative Descriptive Analysis.

Parameter Description

Appearance ${ }^{1}$

Marbling Intermingling of fat with lean on the cut surface of the meat.

Colour intensity Intensity of darkness of lean meat.

Exudate $\quad$ Exuded material in pork samples.

Odour intensity $^{2}$ Intensity of odour perception in the nasal cavity.

Flavour $^{2}$

Skatole Manure flavour.

Sweetness Basic taste sensation elicited by sugar.

Metallic Flavour similar to a solution of $\mathrm{FeSO}_{4} \cdot 7 \mathrm{H}_{2} \mathrm{O}$.

Off-flavours Flavour differing from the typical flavour of meat.

Texture $^{2}$

Hardness Amount of pressure required to completely compress the sample.

Crumbliness Ease with which a sample can be broken into smaller particles during mastication.

Juiciness Moisture felt inside the mouth as a result of meat mastication.

Fibrousness Perception of muscle fibres during mastication.

Overall liking $^{2} \quad$ Hedonic perception.

\footnotetext{
${ }^{1}$ Assessed in raw meat. ${ }^{2}$ Assessed in cooked meat.
} 
Table 2. Quality parameters showing significant differences $(\mathrm{p}<0.05)$ between breeds.

\begin{tabular}{rccccccc} 
& Duroc & Landrace & $\begin{array}{c}\text { Large } \\
\text { White }\end{array}$ & Piétrain & RMSE & $\begin{array}{c}\text { Sig } \\
\text { Breed }\end{array}$ & $\begin{array}{c}\text { Sig } \\
\text { Batch }\end{array}$ \\
\hline Growth performance & & & & & & & \\
Average daily gain (g) & $919.8^{\mathrm{ab}}$ & $890.3^{\mathrm{b}}$ & $942.9^{\mathrm{a}}$ & $844.0^{\mathrm{b}}$ & 93.4 & $<0.01$ & - \\
Average daily feed intake (g) & $2040.4^{\mathrm{a}}$ & $2049.1^{\mathrm{a}}$ & $2139.5^{\mathrm{a}}$ & $1696.0^{\mathrm{b}}$ & 182.6 & $<0.001$ & - \\
Feed conversion ratio & $2.23^{\mathrm{a}}$ & $2.31^{\mathrm{a}}$ & $2.28^{\mathrm{a}}$ & $2.02^{\mathrm{b}}$ & 0.17 & $<0.001$ & - \\
Slaughter weight (kg) & $117.5^{\mathrm{a}}$ & $116.2^{\mathrm{a}}$ & $118.4^{\mathrm{a}}$ & $103.4^{\mathrm{b}}$ & 10.5 & $<0.001$ & -
\end{tabular}

Carcass characteristics

$\begin{array}{rccccccc}\text { Carcass weight }(\mathrm{kg}) & 84.98^{\mathrm{a}} & 82.98^{\mathrm{ab}} & 84.41^{\mathrm{a}} & 75.88^{\mathrm{b}} & 1.66 & <0.001 & \text { NS } \\ \text { Killing out }(\%) & 72.24^{\mathrm{ab}} & 71.38^{\mathrm{bc}} & 71.09^{\mathrm{c}} & 73.76^{\mathrm{a}} & 1.42 & <0.001 & \text { NS } \\ \text { f34fom }(\mathrm{mm}) & 17.30^{\mathrm{a}} & 17.20^{\mathrm{a}} & 16.88^{\mathrm{a}} & 13.36^{\mathrm{b}} & 2.96 & <0.001 & \text { NS } \\ \text { m34fom }(\mathrm{mm}) & 52.03^{\mathrm{b}} & 51.09^{\mathrm{b}} & 50.75^{\mathrm{b}} & 60.14^{\mathrm{a}} & 4.29 & <0.001 & \mathrm{NS} \\ \text { Estimated carcass lean }(\%)^{1} & 58.92^{\mathrm{b}} & 58.87^{\mathrm{b}} & 59.11^{\mathrm{b}} & 63.61^{\mathrm{a}} & 2.90 & <0.001 & \mathrm{NS} \\ \text { Carcass length }(\mathrm{cm}) & 85.31^{\mathrm{c}} & 89.38^{\mathrm{a}} & 86.81^{\mathrm{b}} & 83.58^{\mathrm{c}} & 2.10 & <0.001 & <0.05 \\ \text { Loin length }(\mathrm{cm}) & 86.85^{\mathrm{b}} & 90.76^{\mathrm{a}} & 87.82^{\mathrm{b}} & 84.22^{\mathrm{c}} & 2.62 & <0.001 & \text { NS }\end{array}$

Meat quality

$\begin{array}{rccccccc}\mathrm{pHu} & 5.61^{\mathrm{a}} & 5.52^{\mathrm{b}} & 5.55^{\mathrm{ab}} & 5.49^{\mathrm{b}} & 0.11 & <0.01 & <0.01 \\ \text { Drip loss }(\%) & 3.04^{\mathrm{c}} & 4.14^{\mathrm{b}} & 3.63^{\mathrm{bc}} & 5.33^{\mathrm{a}} & 1.50 & <0.001 & \mathrm{NS} \\ \text { Androstenone }(\mu \mathrm{g} / \mathrm{g} \text { fat) } & 0.98^{\mathrm{a}} & 0.17^{\mathrm{b}} & 0.35^{\mathrm{b}} & <0.10^{\mathrm{b}} & 0.49 & <0.001 & <0.01 \\ \text { Marbling } & 4.79^{\mathrm{a}} & 4.02^{\mathrm{ab}} & 3.67^{\mathrm{b}} & 2.15^{\mathrm{c}} & 1.35 & <0.001 & <0.001 \\ \text { Cohesiveness } & 0.40^{\mathrm{b}} & 0.43^{\mathrm{a}} & 0.44^{\mathrm{a}} & 0.44^{\mathrm{a}} & 0.02 & <0.001 & \mathrm{NS} \\ \text { Hardness }(\mathrm{kg})^{2} & 96.47^{\mathrm{b}} & 125.64^{\mathrm{a}} & 111.46^{\mathrm{ab}} & 96.43^{\mathrm{b}} & 26.32 & <0.001 & \mathrm{NS} \\ \text { Chewiness }(\mathrm{kg})^{2} & 18.31^{\mathrm{b}} & 26.42^{\mathrm{a}} & 22.64^{\mathrm{ab}} & 18.19^{\mathrm{b}} & 6.65 & <0.001 & \mathrm{NS} \\ \text { Moisture }(\%) & 74.06^{\mathrm{b}} & 74.28^{\mathrm{b}} & 74.43^{\mathrm{ab}} & 75.08^{\mathrm{a}} & 0.89 & <0.05 & \mathrm{NS} \\ \mathrm{IMF}(\%) & 3.46^{\mathrm{a}} & 2.66^{\mathrm{b}} & 2.72^{\mathrm{b}} & 2.06^{\mathrm{b}} & 1.12 & <0.01 & \mathrm{NS} \\ \text { Protein }(\%) & 21.9^{\mathrm{b}} & 22.55^{\mathrm{a}} & 22.34^{\mathrm{ab}} & 22.36^{\mathrm{ab}} & 0.76 & <0.05 & \mathrm{NS}\end{array}$

RMSE: root mean square error. Sig: statistical significance of model factors. Batch: slaughtering batch. f34fom: fat depth measured with Fat-O-Meat'er. m34fom: muscle depth measured with Fat-O-Meat'er. $\mathrm{pH}_{\mathrm{u}}: \mathrm{pH}$ at 24 h post-mortem. IMF: intramuscular fat. ${ }^{1}$ Estimated lean (Commission Decision 2009/11/CE). ${ }^{2}$ Texture Profile Analysis. NS: non-significant. 
Table 3. Significant correlation coefficients between quality parameters and protein peak intensities obtained with the CM10 protein chip array in Longissimus thoracis muscles.

\begin{tabular}{|c|c|c|c|c|c|c|c|c|c|c|c|c|c|c|c|}
\hline \multirow[b]{2}{*}{ Parameter } & \multicolumn{15}{|c|}{ Peak $(\mathrm{m} / \mathrm{z})$} \\
\hline & 2,891 & 4,156 & 4,338 & 4,525 & 5,015 & 5,082 & 5,348 & 8,126 & 8,464 & 8,485 & 8,677 & 9,398 & 12,223 & 12,434 & 16,935 \\
\hline Drip loss & & & & & & & 0.361 & & & & & & 0.360 & 0.408 & \\
\hline Androstenone & 0.350 & & & & & & & & & & & & & & \\
\hline Cohesiveness ${ }^{1}$ & & & & & & & & & & & & 0.275 & 0.293 & 0.340 & \\
\hline Initial yield force ${ }^{2}$ & 0.295 & 0.323 & 0.382 & 0.284 & -0.271 & & & & -0.376 & 0.335 & & & & & \\
\hline Total work ${ }^{2}$ & -0.293 & -0.305 & -0.496 & -0.283 & 0.281 & -0.380 & & & 0.426 & -0.427 & -0.302 & & & & \\
\hline Cooking loss & 0.202 & 0.409 & 0.318 & 0.290 & & & & 0.310 & -0.370 & 0.339 & & 0.315 & 0.368 & 0.339 & 0.289 \\
\hline Colour intensity & 0.306 & 0.298 & & 0.367 & & & & 0.374 & & & & 0.345 & 0.293 & & \\
\hline Skatole $^{3}$ & 0.311 & & & & & & & & & & & 0.290 & & & \\
\hline Hardness ${ }^{3}$ & & & 0.311 & & & & & & & 0.331 & 0.278 & & 0.278 & 0.286 & \\
\hline Crumbliness $^{3}$ & & & -0.409 & & 0.330 & & & -0.350 & 0.382 & -0.407 & -0.313 & & & & \\
\hline Juiciness $^{3}$ & & -0.357 & -0.289 & & & & & & 0.308 & -0.294 & & & -0.290 & -0.313 & -0.289 \\
\hline
\end{tabular}

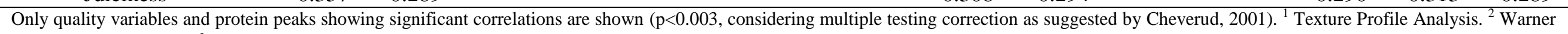
Bratzler shear force test. ${ }^{3}$ Sensory analysis. 
Table 4. Significant correlation coefficients between quality parameters and protein peak intensities obtained with the Q10 protein chip array in Longissimus thoracis muscles.

\begin{tabular}{|c|c|c|c|c|c|c|}
\hline \multirow[b]{2}{*}{ Parameter } & \multicolumn{6}{|c|}{ Peak $(\mathrm{m} / \mathrm{z})$} \\
\hline & 3,201 & 3,743 & 4,436 & 5,147 & 6,554 & 12,119 \\
\hline Drip loss & -0.358 & & & & -0.292 & -0.340 \\
\hline $\mathrm{L}^{*}$ & -0.347 & & & & & \\
\hline$a^{*}$ & & & & & & -0.359 \\
\hline $\mathrm{b}^{*}$ & -0.295 & 0.366 & 0.392 & 0.485 & & 0.353 \\
\hline Initial yield force $^{1}$ & & & & & & -0.322 \\
\hline Total work ${ }^{1}$ & & & & & & 0.287 \\
\hline Cooking loss & & & & & & -0.355 \\
\hline Colour intensity $^{2}$ & & & -0.265 & & & \\
\hline Hardness ${ }^{2}$ & & & & & & 0.348 \\
\hline
\end{tabular}


1 Table 5. Significant correlation coefficients between quality parameters and 2 protein peak intensities obtained with the IMAC30 protein chip array in $3 \quad$ Longissimus thoracis muscles.

4

\begin{tabular}{|c|c|c|c|c|}
\hline \multirow[b]{2}{*}{ Parameter } & \multicolumn{4}{|c|}{ Peak (m/z) } \\
\hline & 3,086 & 4,046 & 6,653 & 8,576 \\
\hline $\mathrm{a}^{*}$ & & & & -0.259 \\
\hline Initial yield force ${ }^{2}$ & & & -0.269 & \\
\hline Cooking loss & & 0.266 & & \\
\hline Marbling ${ }^{3}$ & -0.331 & & & \\
\hline Sweetness $^{3}$ & -0.254 & & & \\
\hline
\end{tabular}

9

10

11 
12 Table 6. Lineal models for quality parameters of Longissiums thoracis muscles.

13

\begin{tabular}{|c|c|c|c|c|c|c|}
\hline \multirow[b]{2}{*}{ Protein array } & \multirow[b]{2}{*}{ Parameter } & \multirow[b]{2}{*}{$\mathrm{r}^{2}$} & \multirow[b]{2}{*}{ RMSE } & \multirow[b]{2}{*}{$\mathrm{SD}$} & \multicolumn{2}{|c|}{ Variables retained in the model } \\
\hline & & & & & peaks $(\mathrm{m} / \mathrm{z})$ & quality parameters \\
\hline \multirow{7}{*}{$\stackrel{O}{\sum_{U}}$} & Drip loss & 0.437 & 1.226 & 1.61 & 12,434 & $\begin{array}{l}\text { Estimated lean } \\
\mathrm{pH}_{\mathrm{u}} \\
\mathrm{L}^{*}\end{array}$ \\
\hline & Cooking loss & 0.266 & 3.172 & 3.66 & 12,434 & Loin yield \\
\hline & Cohesiveness $^{1}$ & 0.365 & 0.022 & 0.03 & $\begin{array}{c}8,677 \\
10,056\end{array}$ & $\begin{array}{l}\text { Cooking loss } \\
\text { IMF }\end{array}$ \\
\hline & Total work ${ }^{2}$ & 0.31 & 9.688 & 11.51 & $\begin{array}{c}4,338 \\
6,158 \\
16,935 \\
\end{array}$ & \\
\hline & Skatole $^{3}$ & 0.132 & 0.111 & 0.12 & $\begin{array}{l}8,126 \\
9,398 \\
\end{array}$ & Estimated lean \\
\hline & Skatole $^{4}$ & 0.156 & 0.568 & 0.61 & $\begin{array}{l}2,891 \\
9,398 \\
\end{array}$ & \\
\hline & Hardness ${ }^{4}$ & 0.441 & 0.691 & 0.91 & $\begin{array}{c}4,338 \\
6,651 \\
10,056 \\
\end{array}$ & Cooking loss \\
\hline \multirow{3}{*}{$\stackrel{\circ}{\circ}$} & Drip loss & 0.448 & 1.219 & 1.61 & $\begin{array}{r}4,507 \\
6,554 \\
12,119 \\
\end{array}$ & $\begin{array}{l}\text { Backfat thickness } \\
\mathrm{pH}_{\mathrm{u}}\end{array}$ \\
\hline & Cooking loss & 0.313 & 3.083 & 3.66 & $\begin{array}{c}5,147 \\
12,119 \\
\end{array}$ & Loin yield \\
\hline & Total work $^{2}$ & 0.233 & 10.215 & 11.51 & $\begin{array}{c}3,201 \\
5,729 \\
12,119\end{array}$ & \\
\hline
\end{tabular}

